\title{
ASSESSING THE IMPACTS OF CITIZEN DELIBERATIONS ON THE HEALTH TECHNOLOGY PROCESS - ERRATUM
}

Abelson, J., Bombard, Y., Gauvin, F., Simeonov, D., Boesveld, S.

doi:10.1017/S0266462313000299, Published by Cambridge University Press, 17 July, 2013.

In the original publication of 'Assessing the Impacts of Citizen Deliberations on the Health Technology Process' the title was published incorrectly. The correct title should be: Assessing the Impacts of Citizen Deliberations on the Health Technology Assessment Process. The publisher regrets this error.

REFERENCE

1. Abelson J., et al. (2013) Assessing the Impacts of Citizen Deliberations on the Health Technology Process. International Journal of Technology Assessment in Health Care, 19:3, 282-2289. doi.10.1017/S0266462313000299. 